\title{
Unemployment Duration and Attitudes Towards Work among People Over 45 Years Old
}

\author{
Tomas Izquierdo-Rus ${ }^{1, *}$ and Francisco J. Moya-Faz ${ }^{2}$ \\ ${ }^{1}$ Department of Methods of Research, University of Murcia, Campus Universitario de Espinardo, 30100, \\ Murcia, Spain \\ ${ }^{2}$ Department of Psychology, Catholic University of Murcia, Campus de los Jerónimos, 30107, Murcia, Spain
}

\begin{abstract}
The situation of global economic crisis and the rapid increase of the unemployment rate cause changes in people's attitudes about the labor market. These changes, sometimes, are motivated by the influence of certain individual variables such as the duration of unemployment. The objective of this research is to analyze the mediator influence of unemployment duration in the attitudes towards work among unemployed people over 45 years old. The people who participate in the research are 161 unemployed that agreed voluntarily in taking part in the interview of attitudes towards work. The data took out from the interviews were analyzed with the statistical software ATLAS.ti 6.2. The results demonstrate that unemployment duration plays an important mediator role in the attitudes towards work when conditioning the job search behavior and favor the chances of finding a job. The conclusion is about practical suggestions and the continuity of research in this area.
\end{abstract}

Keywords: Unemployment, attitudes towards work, unemployment duration, people over 45 years old, qualitative study.

\section{INTRODUCTION}

The situation of global economic crisis with the following job loss has made unemployment one of the major concerns in society. The answers offered by public service, regarding active work policies, are insufficient to assist people over 45 years old considering their complex situation in the labor market. It is necessary to do research studies that analyze the reality of this age group and offer specific proposals of intervention in order to increase their possibilities of job integration or re-integration.

There have been few research studies that analyzed the influence of mediator variables in the unemployment of people over 45 years old, since the predominant vision was based on the market processes and an excessive worrying in quantifying the number of unemployed people. The interest in the study of the psychological consequences caused by unemployment in individuals is revealed in aspects such as the perception of the causes, people behavior in the labor market or the attitudes towards work. Eby and Buch [1] identified the prevalence of a series of intrinsic factors (psychological) as determiners in job search, above the purely economical ones.

*Address correspondence to this author at the Department of Methods of Research, University of Murcia, Campus Universitario de Espinardo, 30100, Murcia, Spain; Tel: +34 868884553; Fax: +34 868888202;

E-mail: tomasizq@um.es
The consequences of job loss, sometimes, are motivated by the influence of mediator variables in the impact caused by unemployment. This has provoked that the psychosocial research about unemployment focuses its attention on the identification of variables that reduce or increase the effects in view of the lack of job. Several authors [2-7] highlight the presence of different factors as mediator variables of the psychological impact that is produced by unemployment in the development of negative attitudes towards work.

There have been few research studies that analyzed the relationship between mediator variables and attitudes towards work, in comparison to the one that has been made about other consequences derived from the lack of job. If we consider those groups with major difficulties of integration, such as young people, women, immigrants, disabled people..., there are just a few research studies that analyzed the influence of mediator variables in this relation. To state Nunes [8], matureness acquired during development is essential for the construction of a satisfactory life course. Turner and Turner [9] observed that the emotional impact of unemployment is stronger in those groups with more difficulties of integration.

Some research studies $[5,10]$ have tried to analyze the attitudes towards work in unemployed people over 
45 years old. In spite of the importance of the matter there are not enough research works held among people over 45 years old, in comparison to other stages of the life cycle $[6,11,12]$. The results reveal that mediator variables affect in general people who do not have a job.

Gender, age, social support, organizational commitment at work, the level of economical income, social class, and the duration of unemployment are the most used variables to analyze the psychosocial consequences of unemployment [4]. The duration of unemployment has been one of the most used variables to explain the heterogeneous nature in the answers towards unemployment. Artazcoz, Benach, Borrell and Cortes [13] point out the necessity of understanding the effects of unemployment considering the interaction of these variables.

The psychological consequences caused by unemployment grow as the period of unemployment extends. Alvaro [14] highlights the existence of an important association between unemployment duration and attitudes. The multi-directional character of its study makes it hard to establish a relation of causality between both variables, although it keeps the need of considering unemployment duration in research studies about the differential psychological impact of unemployment among the unemployed population. Kulik [15] supports this hypothesis when concluding that a shorter time of unemployment contributes to a better attitude towards search.

Motivation plays an essential role since it is considered an important predictor of the job search intensity in long term unemployed people. Del Pozo, Ruiz, Pardo and San Martin [16] observe that the attitudes tend to become worse progressively as the duration of unemployment extends. The attitudes determine the job search intensity and, sometimes, determine the following success in job integration [17].

The expectancy-valence theory becomes a useful framework to understand the attitudes in the context of work integration. However, Aramburu-Zabala [18] suggests the need of revising certain aspects of this theory in relation to the specific scope of job search. This need contrast with the inclusion of concepts such as the individual's attitude towards job search proposed by Vinokur, Ryn, Gramlich and Price [19]. Lind-Stevenson [20] concludes that the individual's expectancy in finding a job facilitates the performance of every behavior tending to an active job search process. The intent of job searching predicts the application of behavior directed to job search. Prusia, Furgate and Kinicki [21] emphasize that the intensity of behavior applied and oriented to job finding predict in a positive way work integration of unemployed people.

The theory of planned behavior (TPB) of Azjen and Madden [22] is another valuable source of information to predict the job search intention. Authors such as Van Hooft, Born, Taris et al. [23] supported the appropriateness of TPB, when finding that the relationship between attitude and search intention was stronger in unemployed people. Those who feel that do not have control on the practice of job search behavior, might refrain from performing it or might not follow their intention of performing that behavior, ignoring their attitudes and subjective norm. However, a person who feels confident in his ability of performing a search behavior is more likely to try to perform the behavior and/or keep his intentions of performing it [24].

In adults over 45 years old the effects of unemployment duration increase due to the lack of balance between education and technological changes [25]. Training becomes an alternative for the acquisition of new professional skills required by the labor market. Stenberg [26] finds a relationship between unemployment and a low participation in formation programs. Unemployment becomes, in this way, an important obstacle to accomplish a complete integration in society [27].

In general, there is a lot of empirical evidence about the influence of unemployment duration in the attitudes towards work. However, this association has not been explored in certain groups of unemployed individuals, neither differences have been established in relation to attitudes towards work among unemployed people. The main goal of this research is to clarify this matter in relation to unemployed people over 45 years old.

\section{METHOD}

Theoretical revisions appear to adopt a methodological position in view of the complex and diverse reality of unemployment, which conditions the selection of a method that is appropriate to understand any social phenomena from the individual's perspective. This research looks for an approach to the reality of the phenomena trough the experience of people over 45 years old. The election of a qualitative methodology implies not only an approach to the reality of unemployment but it also emphasizes, according to 
Leon and Montero [28], the discovery and description of the particular.

\section{Participants}

In this research 161 unemployed people from Andalucia (South region of Spain) took part, through the data obtained by the Regional Employment Office. Distributed, according to gender, 118 are women and 43 men, all adults over 45 years old. During the research they have been told the purpose of the research and they have been guaranteed, at all time, the anonymity and confidential use of the answers obtained.

\section{Measure}

The instrument for data collection was the interview about attitudes towards work, after guaranteeing the fulfillment of the technical requirements of reliability and validity [6]. This instrument is composed by thirty three themes grouped in the following dimensions: work centrality, work explanation, personal and professional self-concept, availability for work, subjective perception of the hiring managers' selections and type of job search.

\section{Procedure}

The participants have been contacted through the computerized data base of the Andalusian Employment Office, regional organism in charge of dealing with employment issues of the Autonomous Community of Andalucia (Spain). The criteria for selecting people consisted of being over 45 years old and being registered in the Andalusian Employment Office. The unemployed people selected were asked to do the interview, after they have been told the nature of the research and that the participation was voluntary. The answers obtained have been transcribed to the word processor Word 2007 and analyzed with the statistical program ATLAS.ti 6.2.

\section{Data Analysis and Interpretation of the Results}

As pointed out above, the aim of this research has been to analyze the effects of unemployment duration in the attitudes towards work in people over 45 years old.

First, it is observed the importance given to work as a mean of personal and professional realization. The participants emphasize what work represents in their lives, favoring their self-esteem, and the benefit derived from the salary earned. Moreover, having a job allows them not only to be useful to society but also to use their personal and professional qualities. These matters show the important role that work has in people's life and its implication in the behavior in relation to job search.

Another aspect observed, considering its direct relation to the centrality of work, is the causal attribution of unemployment. There are different causes showed by the participants, among which there are internal and external causes. One of the most outstanding causes is age, as internal cause of the lack of job, regarding the person. Another, more related to the external is connected to the present economic crisis. Both, either internal or external, determine in a considerable way the behavior in unemployed people.

Regarding self-concept, the people interviewed point out a series of characteristics about their personal and professional image. The participants highlight as their main quality their work experience. Also, they emphasize a series of personal qualities needed to their professional performance, offering dedication and responsibility required in any job position. In the answers gathered, it can be observed a balance in the characteristics implied in personal and professional self-concept.

The participants show availability to work. They show availability for the job if it is in accordance with the labor law and if does not imply a risk for their health. They point out as a priority those jobs related to their formation that offer more stability. As previous conditions in the election, they highlight the necessity of being enrolled with security contract and, mainly in female gender, the compatibility with family. This condition is related to the centrality given to work and, particularly, with the economical need. This limitation is related to the economical need perceived, at a personal or familiar level, in the centrality attributed to work. Nevertheless, the participants demonstrate a high level of availability to work.

The selection criteria applied by the company owners is perceived as part of the attitudes towards work in people over 45 years old. The interviewed people express that age is the main limitation they face in their job search. Other criteria kept by the company owners are gender and work experience. Closely related to causal attribution, emerges the importance of internal aspects such as appearance or external such as luck. In the same way, the economical situation and 
the time without a job are perceived by the interviewed people. All of the above show the role that can play certain characteristics perceived and determines, in a considerable way, the job search behavior.

Finally, it is observed the type of job search showed by the interviewed people. There are different sources used in job search, among which, are found the contact with other people, going to the job office and the use of the internet. An important number of participants do all the activities in their hands to find a job position. The answers gathered consist of the reason why they use one or another. However, other participants do not perform any of the job search activities. This double placement is related to the causal attribution of unemployment: external attributions reduce negatively the job search and internal attributions increase considerably the job search.

\section{CONCLUSIONS AND DISCUSSION}

The identification of variables that explain the heterogeneity of answers is an important part of psychosocial research about unemployment since it would allow the prediction of attitudes towards work. These research studies would help not only to know the differences in the negative impact of unemployment but also would constitute an important contribution to the interventions to be held with unemployed people. Intervention certainly gains importance in a period when work orientation is focused basically in the motivation and the support of motivated behavior towards employment [29], what facilitates the confidence in the use of the abilities each one has to find a job [30].

This research study has allow us to approach to a social reality that has not been specifically studied yet in our country, giving us the chance of a first close proximity to the study of the effects of unemployment duration. The study of this variable in the unemployed population becomes relevant, since it can help clarify the incidence in the attitudes towards work of unemployed people over 45 years old. This was the purpose of the analysis of the following dimensions: job centrality, causal attribution of unemployment, availability for the job, managers' hiring decisions, and type of job search.

The results obtained reveal that the participants tend to consider that job occupies a central role in their lives. Moreover, it is observed a worrying about the situation of unemployment, with attributions both internal and external. Being unemployed not only is the result of external conditions such as the economic crisis but also of personal characteristics such as formation or work experience. Similar results were found in Garcia and Garcia [3] in Africa, Izquierdo [6] in Spain, Izquierdo and Alonso [10] in South America and Schafgans [31] in Asia.

Unemployed people over 45 years old share a positive opinion of their personal and professional appearance and a high availability for job search, which reveal their commitment in overcoming the unemployment situation. They show a rejection towards submerged economy and precarious contracts and working part time in certain circumstances (familiar, economical...) There is evidence that they highlight the importance of self-concept and the availability in job finding $[6,32]$

Among the attitudes towards work it is studied in the last place the subjective perception of the managers' hiring decisions and the type of job search. Certain characteristics are perceived as successful in the selection and an active job search pervades in the participants. The consideration of external attributions and the no realization of job search activities reduce considerably the opportunities. Other situations such as the perception of compensations can condition the active job search [33].

The results of this research reveal that the duration of unemployment plays the role of mediator variable in the attitudes towards work of unemployed people over 45 years old. Adopting a qualitative methodology in the study of unemployment has allow us to 'understand the perspectives and experiences of the interviewed people' [34] and to be based on the narrations made by people who have lost their job [35].

In contrast with quantitative research, the use of qualitative research allows to know the mechanisms and processes that turn unemployment into a different experience in each of the affected people. Moreover, the instrument of information gathering allows not only an exploration of the attitudes towards work in groups with more difficulties of insertion but also a tool for the intervention in orientation programs.

The use of a qualitative methodology can be useful to start new research that aims to analyze the attitudes towards work in other social groups and cultural contexts. The inclusion of young people, women, immigrant, disabled, etc, will allow us to extract the 
distinguishing mechanisms of unemployment in each of the groups. Also, the economical, social and cultural contexts are very important, due to the big differences between countries in relation to the unemployment rate, poverty index and social compensations for unemployed people [36].

It is necessary to do other research studies that include other variables that could give more sense to the individual experience of unemployment. Variables such as gender, educational level, economical resources, and social support that may have a mediator effect in unemployed people. When analyzing the duration of unemployment it would be convenient, also, to blend the periods of unemployment since it does not exist a settled criteria in the established periods [6].

The results of this study have practical implications since they can lead to the development of activities that benefit a change of attitude in unemployed people over 45 years old. The identification of mediator variables [37] conditions the success in finding a job through taking part in specific professional orientation programs. The occupational formation acquires a relevant importance since it affects in a positive way the attitudes towards work and, consequently, increases the possibility of insertion [32]. The higher the motivation the more search activities performed [38], which increases the probability of finding a job.

\section{REFERENCES}

[1] Eby LT, Buch K. The effect of job search method, sex, activity level, and emotional acceptance on new job characteristics: implications for counseling unemployed professionals. J Emp Couns 1994; 31(2): 69-82. http://dx.doi.org/10.1002/j.2161-1920.1994.tb00416.x

[2] Buendía J. El impacto psicológico del desempleo. Murcia: Editum 2010.

[3] García AM, García MG. La influencia de los rasgos psicológicos en las actitudes hacia el empleo. Revista de Psicología del Trabajo y de las Organizaciones 2008; 24(2): 203-233.

[4] Garrido A. Sociopsicología del Trabajo. Barcelona: UOC 2006.

[5] Izquierdo T. Actitudes hacia el trabajo de los desempleados mayores de 45 años. Granada: EUG 2005.

[6] Izquierdo T. El desempleo en los mayores de 45 años. Jaén: CES 2008 .

[7] Izquierdo T. Los nuevos retos del mercado laboral: una perspectiva desde la orientación profesional. Úbeda: Amarantos 2010.

[8] Nunes I. Motivational dynamics in the development of career attitudes among adolescents. J Voc Behav 2010; 76(2): 170177. http://dx.doi.org/10.1016/j.jvb.2009.12.003

[9] Turner JB, Turner RJ. Physical disability, unemployment and mental health. Reh Psych 2004; 49(3): 241-249. http://dx.doi.org/10.1037/0090-5550.49.3.241
[10] Izquierdo T, Alonso HJ. Valores culturales y consecuencias psicosociales del desempleo en América Latina. Revista de Psicología del Trabajo y de las Organizaciones 2010; 26(2): 123-133.

http://dx.doi.org/10.5093/tr2010v26n2a4

[11] Izquierdo T, Hernández $F$. Orientación profesional y desempleo adulto. En J. Maquilón et al. Coords. Cambios educativos y formativos para el desarrollo humano $y$ sostenible Murcia: Editum 2011; pp. 519-526.

[12] Izquierdo T, Hernández F, Maquilón J. Psicología del ciclo vital en el desempleo adulto. En: Actas del I Congreso Internacional de Psicología del Trabajo y de las Organizaciones 2010; Buenos Aires, Argentina.

[13] Artazcoz L, Benach J, Borrell C, Cortes I. Unemployment and mental health: understanding the interactions among gender, family roles and social class. Am J Pub Heal 2004; 94(1): 8288.

http://dx.doi.org/10.2105/AJPH.94.1.82

[14] Álvaro JL. Desempleo y bienestar psicológico. Madrid: Siglo XXI 1992.

[15] Kulik L. Impact of length of unemployment and age of jobless men and women: A comparative analysis. J Emp Couns 2001; 38(1): 15-27.

http://dx.doi.org/10.1002/j.2161-1920.2001.tb00489.x

[16] Del Pozo JA, Ruiz MA, Pardo A, San Martín R. Efectos de la duración del desempleo entre los desempleados. Psicothema 2002; 14(2): 440-443.

[17] Wanberg CR, Kanfer R, Rotundo M. Unemployed individuals: Motives, job-search competencies, and job-search constraints as predictors of job seeking and reemployment. $\mathrm{J}$ App Psych 1999; 84(6): 897-910. http://dx.doi.org/10.1037/0021-9010.84.6.897

[18] Aramburu-Zabala L. Determinantes psicosociales de la búsqueda de empleo. Revista de Psicología del Trabajo y de las Organizaciones 1998; 14(3): 315-331.

[19] Vinokur AD, Van Ryn M, Gramlich E, Price RH. A long term follow-up and cost-benefit analysis of a successful preventive intervention for the unemployed. J App Psych 1991; 76: 1-7. http://dx.doi.org/10.1037/0021-9010.76.2.213

[20] Lynd Stevenson RM. Expectative-value theory and predicting future employment status in the young unemployed. J Occup Org Psych 1999; 72(1): 101-106. http://dx.doi.org/10.1348/096317999166527

[21] Prusia GE, Furgate M, Kinicki AJ. Explication of the coping goal construct: Implications for coping and reemployment. J App Psych 2001; 86(6): 1179-1190. http://dx.doi.org/10.1037/0021-9010.86.6.1179

[22] Ajzen I, Madden TJ. Prediction of goal-directed behavior: Attitudes, intentions, and perceived behavioral control. J Exp Soc Psych 1986; 22: 453-474. http://dx.doi.org/10.1016/0022-1031(86)90045-4

[23] Van Hooft EA, Bom MP, Taris TW, et al. Predictors of job search behavior among employed and unemployed people. Pers Psych 2004; 57(1): 25-35.

http://dx.doi.org/10.1111/j.1744-6570.2004.tb02483.x

[24] Smith B, Stasson M. A comparison of health behavior constructs: Social psychologycal predictors of AIDS preventive behavioral intentions. J App Soc Psych 2000; 30: 443-462. http://dx.doi.org/10.1111/j.1559-1816.2000.tb02490.x

[25] Olechnowicz A. Unemployed workers, "enforced leisure" and education for the right use of leisure in Britain in the 1930's. Lab Hist Rev 2005; 70(1): 27-52. http://dx.doi.org/10.3828//hr.70.1.27

[26] Stenberg A. Comprehensive education for the unemployed evaluating the effects on unemployment of the adult education initiative in Sweden. Labour 2005; 19(1): 123-146. http://dx.doi.org/10.1111/j.1467-9914.2005.00293.x 
[27] Kieselbach T. Long-term unemployment among young people: the risk of social exclusion. Am J Com Psych 2003; 32(1), 69-76. http://dx.doi.org/10.1023/A:1025694823396

[28] León O, Montero I. Métodos de investigación en psicología y educación. Madrid: McGraw-Hill 2010.

[29] Altuna A. El rol del orientador: tomas de posición para una orientación laboral más efectiva. Capital Humano 2005; 192: 109-115.

[30] Gelpe D. Motivation in formation in unemployed subjects and professional aspirations. Bull Psych 2001; 54(3): 251-260.

[31] Schafgans MMA. Gender wage differences in Malasya: parametric and semiparametric estimation. J Develop Econ 2000; 63(2): 351-378. http://dx.doi.org/10.1016/S0304-3878(00)00114-0

[32] Martínez MF, García M, Maya I. El rol del apoyo social y las actitudes hacia el empleo en el emplazamiento laboral de inmigrantes. Anuario de Psicología 2001; 32(3): 51-65.
[33] García I, Toharia L. Prestaciones por desempleo y búsqueda de empleo. Revista de Economía Aplicada 2000; 23(8): 5-33.

[34] Buendía L, Colás $P$, Hernández $F$. Métodos de investigación en psicopedagogía. Madrid: McGraw-Hill 2003.

[35] García Calavia MA. La lógica de los trabajadores. Un estudio sobre la racionalidad, la autonomía y la coherencia de las prácticas y los significados de los trabajadores. Revista Internacional de Sociología 2008; 51: 123-144.

[36] Gallardo J. Juventud, trabajo, desempleo e identidad: un enfoque psicosocial. Athenea Digital 2011; 11(3): 165-182.

[37] Tango RA, Kolodinsky P. Investigation of placement outcomes 3 years after a job skills training program for chronically unemployed adults. J Emp Couns 2004; 41(2): 80-92. http://dx.doi.org/10.1002/j.2161-1920.2004.tb00881.x

[38] McFadyen RG, Thomas JP. Economic and psychological models of job search behavior of the unemployed. Hum Rel 1997; 50(12): 1461-1484.

http://dx.doi.org/10.1177/001872679705001201

DOI: http://dx.doi.org/10.6000/2292-2598.2014.02.03.4

(C) 2014 Izquierdo-Rus and Moya-Faz; Licensee Lifescience Global.

This is an open access article licensed under the terms of the Creative Commons Attribution Non-Commercial License (http://creativecommons.org/licenses/by-nc/3.0/) which permits unrestricted, non-commercial use, distribution and reproduction in any medium, provided the work is properly cited. 